\title{
Modeling an Islamic Student Financing Securitization*
}

\author{
Mohammed Hariri BAKRI ${ }^{1}$, Shafinar ISMAIL ${ }^{2}$, Samer AL-SHAMI ${ }^{3}$, Nurazilah ZAINAL ${ }^{4}$, \\ Abdul Rahim RIDZUAN ${ }^{5}$
}

Received: August 01, 2020 Revised: September 06, 2020 Accepted: September 10, 2020

\begin{abstract}
The study investigates developing an Islamic student financing securitization model based on sukuk structures. This study employs sample of descriptive, analytical, and comparative analyses utilized to discuss a novel framework of Islamic securitization through the different structures of sukuk wakalah derived from asset securitization. The result served to investigate the use of Islamic student financing securitization in a Shariah-compliant manner, which would be implementable in Malaysia. It emphasized the sukuk structures based on the wakeel principle, which indicated a situation where a wakeel or representative appointment was made to manage a project on the behalf of the sukuk holder. The findings of this study supported the economic benefits obtained in the form of lower overall financing costs through the use of securitization for student financing in higher education. This paper offers important implications specifically for the creation of sukuk structures and issuing a highly graded and marketable sukuk, which are compliant towards global Shariah principles. The paper fills the gap perceived within the existing literature of Islamic finance by showing Islamic securitization via sukuk as a viable source of funds potential utilizable in stabilizing the securities market. It can also pose as a solution for securing a sustainable funding.
\end{abstract}

Keywords: Securitization, Islamic Financing, Student Financing, Sukuk Wakalah, Kafalah

JEL Classification Code: G11, G12, G13

\begin{abstract}
*Acknowledgements:
In order to complete this paper, the authors would like to thank Oxford Centre for Islamic Studies and Ministry of Education Malaysia for their support providing necessary funding and placement as Visiting Research Fellow at Oxford, thanks Dr. Muhammad Meki (University of Oxford) supporting the review of the paper and final results for the authors in the research process. The authors also thank the Faculty of Technology Management and Technopreneurship, Universiti Teknikal Malaysia Melaka, Malaysia and Centre of Technopreneurship Development, Universiti Teknikal Malaysia Melaka

${ }^{1}$ First Author and Corresponding Author. Associate Professor, Faculty of Technology Management and Technopreneurship, Universiti Teknikal Malaysia Melaka, Malaysia [Postal Address: Melaka, Hang Tuah Jaya, Durian Tunggal, Melaka,76100 Malaysia] Email: hariri@utem.edu.my ${ }^{2}$ Professor, Faculty of Business and Management, UiTM Melaka, Malaysia. Email: shahfinar@uitm.edu.my

${ }^{3}$ Institute of Technology Management and Technopreneurship, Universiti Teknikal Malaysia Melaka, Malaysia. Email: samerali@utem.edu.my ${ }^{4}$ Senior Lecturer, Faculty of Business Administration, UiTM Seremban, Malaysia. Email: nuraz3169@uitm.edu.my

${ }^{5}$ Senior Lecturer, Faculty of Business and Management, UiTM Melaka, Malaysia. Email: rahim670@uitm.edu.my

(c) Copyright: The Author(s)

This is an Open Access article distributed under the terms of the Creative Commons Attribution Non-Commercial License (https://creativecommons.org/licenses/by-nc/4.0/) which permits unrestricted non-commercial use, distribution, and reproduction in any medium, provided the original work is properly cited.
\end{abstract}

\section{Introduction}

Asset securitization may pose as a strategy in issuing securities, namely, by offering financial resources with a competitive rate. Its motivation is positioned towards finding financial resources for funding or as an instrument to obtain new assets at a progressively lower cost, which is in contrast to assets being sourced through direct acquisition from financial institutions. Resource-supported protections are generally perceived as having numerous points of interest over the conventional types of financing. This instrument incorporates the lower cost of subsidizing, improvement in the originator's and liquidity, and expansion of financing sources. From a financial specialist's viewpoint, venture openings are widened with the variety of funding and adaptability made conceivable through securitization. As far as improving the capital markets and economy, the issuance of Islamic securitization will boost the liquidity and become an increasingly viable portion of capital, in general. An asset that is normally securitized includes house financing, receivable record, credit card account, vehicle financing receivable record, roadway toll aggregation, and 
more. According to the Islamic setting, all assets must be securitized as per the Shariah requirements.

\section{Sustainability Education Funding}

\subsection{Overview of Student Financing}

According to human capital theory, an individual is generally willing to invest in their higher education and treats such effort as a commodity. This is due to employer recognition for those who have formal higher education, who are thus compensated or remunerated based on their education qualification. Furthermore, the demands for higher education levels are increasing as graduates require good and promising career options that offer higher remunerations (Sarpong, 2002). Higher return from educational investment is one of the determinants inducing the increased demand for higher education. However, students should undertake an analysis before making their decision to enter any higher education especially in the private higher education that should be included in the review of the higher education literature. Menon (1998) has underlined the Robbins Committee's explanation of the main factor in influencing the demand for private higher education in year 1963 in United Kingdom. The results have proven that certain variables impact society such as cost of tuition and qualification, based on level of education in prospective employers and are, as well as family background and economic are needed (Hsing \& Chang, 1996), financial aid for students (Michael, 1999), and family income (Mueller \& Rockerbie, 2004).

Therefore, one of the solutions for the increased demand of higher education is to offer student financing. As anticipated, the tuition fees have steadily increased in the United States, the UK, Netherlands, Japan, Australia, New Zealand, Portugal, and Austria. According to the OECD's Education Glance 2011 as cited by Willet (2011), 14 out of 25 countries (for which data is available) reformed their tuition fees and support for students since 1995. Due to student financing being increasingly demanded for in developed and developing countries both, an alternative to reduce or transfer such financial burden from the students and their parents to the government should be present (Woodhall, 1987; Johnstone, 1986). As such, the "study now, pay later" mind set, which is otherwise called as deferred payment, is one of the strategies available to increase the demand for furthering studies in higher education (Sharif et al., 2018).

Typically, human capital investment in the absence of a collateral is riskier compared to other forms of investment. Financing student loans themselves are further perceived as a precarious and uncertain investment (Friedman, 1955). Therefore, an alternative solution in reducing such notable risk is the introduction of asset-back securitization in financing these student loans, which are thus backed by bonds (Lazzaro, 2008) in raising the educational funds. Accordingly, Fan et al. (2004) have defined asset-backed securities as a process of raising funds that are backed from revenue-producing assets, which generate future cash flows. However, asset securitization differs from a normal loan as the loan is repackaged and sold to a third party, such as Special Purpose Vehicle (SPV) (Bakri et al., 2015). According to Giddy (2004), asset-backed securities which SPV issues ones or more debt instrument, will include an interest, while the principal payments are dependent on the cash flows that come from the underlying assets.

\subsection{Overview of the Crisis}

As of May 2019, the National Higher Education Fund Corporation (NHEFC) disbursed loans for about three million people to further studies with the real dispersed remained at RM56 billion (NHEFC, 2019). Further measurements by the corporation have demonstrated that albeit numerous NHEFC borrowers are demonstrating their enthusiasm to make payment, the real total amount gathered remains low. Shockingly, around $37 \%$ of the appropriated credit has gone to those who enrolled in private loan education establishments (IPTS) yet the amount obtained by this percentage spoke to practically $50 \%$ of the all-out designation. Out of the absolute credit dispensed summing up to RM56 billion, merely RM8.4 billion get reimbursed, where RM2.8 billion borrower never paid once made up of 356,000 borrowers. Meanwhile, sources from the partnership guarantee that around $23 \%$ of those who paying back their loans are doing so reliably. Nonetheless, in view of the Malaysia of Higher Education's 2018 Graduate Tracking Survey, around 23\% of the current alumni in the nation are unemployed still.

A review of the literature on student financing is not a priority in past research work in Malaysia (Ismail et al., 2014), whereby most of such works on the topic have been undertaken in USA (Hartung et al., 2006). Therefore, this article is looking to examine student-financing securitization as an alternative financing option in Malaysian higher education industry so as to minimize student dependence on the government budget. The researcher aims to analyze the suitability of introducing student financing securitization as new instrument to raise funding. Hence, Malaysia will be the first country to introduce Islamic student financing securitization through sukuk, which is a new concept itself for Malaysian higher education (Bakri et al., 2016). It offers a cheaper rate at $3 \%$ compared to the current borrowing of $5 \%$ from conventional financial institutions (NHEFC, 2019). Although the National Higher Education Fund only charges ijarah $1 \%$, the government needs to find an alternative instrument to reduce the cost of financing. In general, different countries have their own ways and systems to raise funding for students going for higher education (Chapman \& 
Harding, 1993; Barr, 2003). Therefore, the corporations and institutions have been set up to handle and manage student financing, which can be offered for university students who are eligible (Chapman et al., 2005).

However, the main reason for student default payment is due to their future unemployment resulting in governmental difficulty in financing new students as they have insufficient fund (Khan, 2008). In Malaysia, the government established NHEFC in 1997 to fund eligible undergraduates in their pursuit for higher education studies (NHEFC, 2013). It is geared specifically for those who meet all requirements to further their studies in higher learning organisations, but did not have financial assistance from the government, such as MARA, JPA, Bank Negara Malaysia, PETRONAS, Telekom, Tenaga Nasional Berhad, and Khazanah. Through NHEFC, help is available for undergraduate students at a lower charge to ensure repayment is less burdensome, whereas the loan is waived if they graduate with a First Class degree; this motivates the student to get good grades.

All things considered, the Malaysian government has allocated a big amount of budget for financing the students who are furthering their studies every year. Unfortunately, the National Higher Education Fund cannot rely on the government budget alone due to its decreasing revenue decreasing since the tax system shift from Good Service Tax (GST) to Sales Services Tax (SST). Furthermore, the government needs to commit to different categories of budget, such as government emolument, housing, and schools (Ziderman, 2004). Likewise, the National Higher Education Fund requested RM2 billion from the government in 2007, which was rejected due to such allocation directed to healthcare, social needs, and other public infrastructure for the public instead. After some consideration, NHEFC has obtained a loan from the Employee Provident Fund (EPF), which is under the Ministry of Finance, but has limited educational funding. The National Education Higher Fund has been request to obtain loan from banks since the government and their agencies have limited resources to maintain student financing for further studies purposes (Ministry of Finance, 2013).

Currently, a student has to pay $1 \%$ if they convert to the Islamic financing scheme although the profit rate is low; instead, high costs of living causes them to still be incapable of repaying their loans (National Higher Education Fund,2013) due to higher commitment. Therefore, the researcher proposes the first Islamic student financing securitization worldwide by issuing sukuk wakalah. Ultimately, the student financing securitization will be offered with lower charges as a source of financing to higher education students as form of alternative of investment to the investor and for those who would like to subscribe to a new type of sukuk. The framework that is currently established to finance higher education student loans from other countries includes income-contingent and mortgage-type loans (Chapman, 2005; Barr, 2003; Ziderman, 2004). Both types of loan have a different method of collection; the income-contingent loan is proportionate to income, whereas the mortgage-type loan repayments are based on a monthly fixed rate. Repayment for the mortgage-type loans generates a fixed monthly repayment rate and repayment contract after graduation as a term for the borrowers (Cartwright et al., 2008).

\subsection{Benefit of Securitization}

Firms may opt to reduce the cost of bankruptcy through Asset-Backed Securities with the risk being transferred through a Special Purpose Vehicle (Ayotte \& Gaon, 2005). Meanwhile, reducing the cost of financing is achievable by asset securitization implemented by the firms. Ali et al. (2015) have supported the findings from a previous study, which have stated that Mortgage-Backed Securities provides higher long-term investment credit rating to financial institutions, such as banks, insurance companies, and fund managers. Hence, the net asset value is increased for financing government staff housing loans in Malaysia. Besides, Lemmon et al. (2014) have testified according to data obtained from non-financial firms across different 10,000 firm disclosures. By using a large database of assetbacked securitizations, they have supported the findings that it offers a lower cost in overall financing and gives a better return on investment to an investor. Due to knowing that the risks are lower compared to firms directly issuing a certificate of traditional bond, this gap becomes the thrust of this study.

\section{Asset Pricing in Islamic Finance}

Black-Scholes-Merton $(1973,1974)$ has become the standard framework of capital structured option pricing theory for the valuation of asset pricing components in Islamic finance in which the lenders payoff under put-call parity. In Islamic finance, the borrower will pay via periodic payment (i.e., premium payment) in terms of implicit interest rate characteristic to the lender for the call position. The notional value, $F$ consists of zero-coupon bond $B$, with the maturity term of $T$ periods being the basis of firm debt, according to the Black-Scholes-Merton approach. This capital-structure-based evaluation of contingent claims on firm performance under the risk-neutral measure implies that a firm defaults if its asset value is insufficient to meet the amount of debt owed to bondholders at maturity Hoda et al. (2020). Conversely, if the "distance to default" is positive and the asset value of the firm exceeds the bankruptcy level, the call option held by equity holders on firm value has an intrinsic value (i.e., in addition to its time value until the maturity of debt) (Phuoc, 2018). 
The price of Islamic finance transactions will be based on this particular approach. Sukuk issuance in Malaysia includes sukuk structures involving sale and purchase of assets under 'uqud mu'awadhat or 'aqd wakalah, which incorporated components of the sale and purchase of assets or commodities murabahah. To curb asset purchase price manipulation in sukuk issuance, the SAC has discussed the issue of asset purchase pricing for the benefit of all parties involved. The asset purchase pricing in sukuk issuance based on the following principles is permissible, subject to the requirements of 'uqud mu 'awadhat (e.g., bai 'bithaman ajil, murabahah, istisna', and ijarah) or 'aqd wakalah (i.e., involves the components of sale and purchase of assets or commodities murabahah). They must not exceed 1.51-fold of the market value for the asset involved, or the fair value or other appropriate value of a particular asset if the market value cannot be ascertained. The previous requirements are not applicable for sukuk structured based on the ijarah principle, as they do not involve sale and purchase of underlying assets.

Islamic securitization transfers the mutual agreement risk between lenders and borrowers based on an underlying pool of assets repackaged and sold to the investor. In its basic concept, originators sell existing or future revenues from the lease receivables (i.e., asset-based), "sale-back profit" (i.e., debt-based), or private equity from a portfolio of Islamicadjacent and acceptable assets to an SPV. It refinances itself by issuing unsecured securities to market investors interested in buying the Islamic bond in the Islamic finance capital market. Islamic securitization must confer upon the investors clearly regarding their identifiable rights and obligations for the securitized assets in order to ensure direct participation in any distribution of risk and reward between the lenders and borrowers, as well as limited risk mitigation and/or indemnification through credit enhancement (Phuoc et al., 2018). Hence, from the Islamic securitization perspective, uncertainty, gambling, and business-related religioussanctioned real economic activity should be avoided.

\subsection{Mortgage Securitization through Sukuk Musharakah}

Islamic securitization in subprime mortgage is based on risk-shifting and differs from the sukuk structures (i.e. mudharabah and musharakah mutanaqisah principles), which are based on the risk-sharing concept. Risk-sharing combines the risk exposure, where the whole risk is less than the total risk on individual parts (Jacobs, 2009). As promoted by Chapra (2008), the financial system may be able to promote justice if, in addition to being strong and stable, it satisfies at least two conditions based on moral value. The entrepreneur will share the losses or risk with the financier, rather than totally shifting the burden to the entrepreneur. According to Islamic principles, the financier and entrepreneur both should share the profit and loss equally, as this will fulfill the first condition of justice. For this purpose, one of the basic principles in Islamic finance is "no risk, no gain"; the principle is introduced to ensure the justice for both sides. Furthermore, the financier needs to assess the risk more carefully by monitoring fund utilisation by borrowers accordingly. Both the financier and entrepreneur need to reduce any excessive lending through the double assessment of risks. The problem of subprime mortgage can be minimized through Islamic finance by offering an affordable credit rate to the borrower. Sukuk will thus be one of the instruments potentially utilised to finance prospective projects based on the Shariah perspective.

As aforementioned, Islamic securitization based on the mudharabah or partnership principle dictates that both the borrower (sukuk users) and financier (investor) will share the profit and bear the risk of losses equally. In the case of musharakah mutanaqisah sukuk, the legal implication dictates that both the investor and homeowner are musharakah partners, but the investor share in the assets (i.e., houses) will diminish over time as the instalments are paid by homeowners to repurchase the assets. In this situation, the agent who administers the sukuk will act as the wakeel, whereas the investors receive the turn of their capital from the instalments in addition to the Islamic securitization rental paid by the homeowners for using the assets. Both parties need to agree on the contract terms and conditions if the flexible characteristics of this kind of sukuk are to be implemented. In contrast, mudharabah sukuk principle uses the concept of risk-sharing, whereby profit or dividend is shared, but not the losses (Hanim et al., 2010). Through this concept of sukuk, there will be no guarantee of capital values and thus differs from musharakah mutanaqisah sukuk. The mudharabah sukuk allocates highly profitable return in the reserve so that they can afford to pay out dividends although the economy is in a bad situation and generate less return compared to musharakah mutanaqisah sukuk(Wilson, 2008).

\subsection{Islamic Student Financing Securitization through Sukuk Wakalah}

Pursuant to a Wakalah agreement entering between the Trustee (acting on the behalf of the holders of the Sukuk Wakalah and the Issuer. The Trustee (acting on behalf of the Sukuk holders) will appoint the Issuer to act as its agent ("Investment Wakeel"), acting on trust for the Trustee and the Sukuk holders, to invest the Sukuk Proceeds into the Shariahcompliant general business of the Issuer ("Shariah-compliant Business"); and Shariah-compliant commodities (excluding ribawi items in the category of medium of exchange such as currency, gold and silver) purchased. The sukuk sold under the Shariah principle of Murabahah (via Tawarruq arrangement), 
collectively, "Wakalah Investments". From time to time, the Issuer will issue Sukuk Wakalah and the Sukuk holders will subscribe to it by paying the issue price ("Sukuk Proceeds"). The Trustee and Investment Wakeel will declare a trust over the Sukuk Proceeds, and over the Wakalah Investments and all of the rights, title, interests, entitlements, and benefits of the Trustee and the Investment Wakeel respectively.

Under the Wakalah Investments and/or the transaction documents in connection with the Sukuk Wakalah Programme ("Transaction Documents"), including all moneys payable thereunder to the relevant Sukuk holders, held on trust by the Trustee and the Investment Wakeel respectively for the relevant Sukuk holders ("Trust Assets"). In this perspective, as an innovative obligation financing that goes about as hazard the board device, in the first half of 2017, Sukuk issuances by the Malaysian government and corporate entities amounted to RM79.01 billion, thus representing 53.3\% of the total bond issuances in the country according to the International Islamic Financial Market's Sukuk Report 2018. Similarly, the 2018 Sukuk report has underlined the Standing Committee for Economic and Commercial Cooperation of the Organisation of the Islamic Cooperation (ECOMCEC) observation regarding the outstanding value of localcurrency Malaysian Sukuk amounting to RM718.4 billion as of late June 2017. This value was significantly higher than the RM534 billion outstanding value of conventional bonds recorded during the same period (Hashim, 2018). At present, the government pays RM1.7 billion annually (NHEFC 2019). Since Islamic securitisation is a piece of Islamic bonds or sukuk in Malaysia that is consistently popularised for financing projects, the researcher proposes the structure for Islamic Student Financing Securitization.

\subsubsection{Originator - NHEFC (Owner)}

National Higher Education Fund Corporation is the owner tasked with transferring the risk or assignment (hawalah) debt to the SPV in the process of Islamic securitization. Normally, the lender will undertake underwriting and do the transactions in loan securitization. National Higher Education owned this asset before transaction transfer takes place to the Special Purpose Vehicle. In this case, the NHEFC is a firm that provides higher education loans to students who wish to pursue higher education at institutions of higher education. It will transfer the asset to the SPV companies appointed to serve as intermediaries before issuing sukuk to investors interested in investing in the NHEFC Sukuk Wakalah.

\subsubsection{Special Purpose Vehicle (SPV)/Wakeef - Corporation/Merchant Banks}

The SPV is a business for particular objectives designed by a financial organization with the exact purpose of buying the portfolio and facilitating the sale. Next, the collateral excellence is evaluated by a credit scoring organization typically, which is tasked with appraising the credit danger of the security and the quantity of credit held in the organization. The credit institution achieves payment for its usual scoring services. In the third step, interest-bearing securities are sold to stakeholders, whereby they obtain an increase as recompense for the credit. Subjected to the normal conditions as extensive-term debt securitization, the SPV pays the stakeholders the interest and principal made by the portfolio cash flow, minus a service charge. In this case, the NHEFC will appoint a merchant bank on their behalf to carry out their duties as a party to carry out related transactions and reports. The appointed SPV consists of a merchant bank or firm with experience in securitisation transactions.

\subsubsection{Buyers - Investors}

An investor is a person that allocates the capital with the expectation of a future financial return and look at brand resonance score for investment (Ande et al., 2017). The types of investments are debt securities. The investor is typically someone who provides a business with capital and someone who buys a stock both, who will invest in sukuk wakalah. This consists of 51\% Tangible Assets and 49\% through financing. They will hold this sukuk for a period of time until it reaches the maturity at an agreed-upon rate. To encourage investor investment, the education ministry will guarantee the sukuk in the event of default payment.

\subsubsection{Hawalah - Assignment of Debt}

Hawalah means transfer of risk or change to other parties. Legally, hawalah is defined as process of transfer from the principal debtor to the transferee in which the liability of debt settlement is transferred. It establishes a new debt between the creditor and transferee before eliminating an existing debt between the creditor and principal debtor, thus creating two new debts before abolishing the new one. Hawalah is not the sales of debt, but rather, it is similar to the concept. The NHEFC will transfer some of the debt to the SPV for the issuance of Sukuk. This is the Islamic concept or principle of debt that cannot be sold, hence the concept of Hawalah is applicable differently in comparison with the concept of housing securitization widely used.

\subsubsection{Kafalah/Rihn - Guarantor (MOE)}

Kafalah is a contract for undertaking the responsibility for liability for others, where a person or corporation accepts as the guarantor. The act states that if failure occurs, someone has to take up the liability and responsibility. In Islamic finance, the borrower or seller will be able to obtain 
recourse if the borrower fails to fulfil the obligation for payments due to services or goods purchased. Therefore, the Ministry of Education (MOE) plays a key role in securing every sukuk issued so that it can continuously source highly critical educational funding at a lower cost compared to loans made through banks or financial institutions with high fees. The application of kafalah for a guaranteed facility by the guarantor in sukuk structures based on 'uqud mu'awadhat, 'uqud ishtirak, and aqd wakalah is wholly permissible. It may be provided either with or without the imposition of a fee. The principle as permissible in sukuk structuring must be executed separately from the underlying contract of sukuk, whereby any termination of the underlying contract does not affect the kafalah and vice-versa.

\subsubsection{Sukuk Wakalah - Instruments/Underlying Asset}

Certificates that represent a project or particular activity carried out according to the wakalah principle, whereby a wakeel or representative is appointed to manage the project on the behalf of the sukuk holder. The structure stems from the concept of wakalah, which is literally translated as an arrangement where one party entrusts another party to act on its behalf. A wakalah is thereby akin to an agency arrangement. A principal (the investor) appoints an agent (wakeel) to invest funds provided by the principal into a pool of investments or assets, and the wakeel lends their expertise and manages the investments on the behalf of the principal for a particular duration to generate an agreed-upon profit return. The principal and wakeel, thus, enter into a wakalah agreement, which governs the appointment, scope of services, and fees payable to the wakeel, if any. The relationship between the two parties must comply with certain basic conditions.

The wakalah structure is particularly useful when the underlying assets available to the originator and can be used to support the issuance of the sukuk are comprised of a pool or portfolio of assets or investments, as opposed to any particular tangible asset or assets. The wakeel thereby uses their expertise to select and manage the investments on the behalf of the investor to ensure that the portfolio will generate the expected profit rate agreed by the principal. While the wakalah structure has some similarities compared to the mudharabah structure, the main difference is that unlike the latter in which the profit is divided between the parties according to certain ratios, an investor via the wakalah structure will only receive the profit return agreed between the parties at the outset. Any profit in excess of the agreed-upon profit return will be kept by the wakeel as a performance or incentive fee.

\subsubsection{Takaful - Protection of NPL}

Takaful operates in view of the best interest for its participant in which a person or organisation performs duty takaful operation with a valid license. It operates according to Shariah-compliant processes in a prudent and sound manner. The takaful frameworks are set up to guide the industry players in monitoring their operational process and safeguarding the best interests of the participants, sustaining the takaful fund (hibah) for a longer period, and achieving the takaful business efficiency. Therefore, the students are protected by takaful in the event of a disaster, where funds will be withdrawn from the grant or participant contribution to repay the loan in the event of their inability to honour repayments due to death and accident that result in the loss of employment and other accidents.

\subsubsection{Trustee}

The Islamic capital market industry provides for the structures in sukuk, whereby in Malaysia, they are governed by a legal regulatory framework. Trustee, as the party governing the industry, plays important roles in establishing sukuk. Every transaction involving sukuk issuance requires a trustee to be appointed, and the trust deed must be executed under the exceptions provided for in Schedule 8 of the Capital Market Services Act 2007 ("CMSA"). Thus, the trust structure is the core theme in sukuk, so far as Malaysia is concerned. In this case, Malaysia Trustee Berhad is appointed as the trustee for Sukuk Wakalah.

To ensure the enforcement of loan payment, the National Higher Education Fund may collaborate with several government agencies to monitor the repayment process.

\subsubsection{AKPK - Counselling Credit}

The agency will impart financial education to the students, delineating the importance of financial literacy before disbursement of loan (Idris et al., 2016). They are made aware of the consequence should a non-performing loan occurs.

\subsubsection{BNM - Central Bank}

Central banks will monitor the repayment process through the CCRIS system in which the borrower will be blacklisted if they failed to make payments for three consecutive months. This aids in minimizing defaulted payments among borrowers for paying off their monthly instalments in order to generate the funds required to help other undergraduates in continuing their higher education.

\subsubsection{KWSP - Employees Provident Fund}

Borrowers who are working in the private sector will make monthly deductions through the Employees Provident Fund (EPF) to the NHEFC, whereby minimum payments are made and their monthly payments will increase as their 


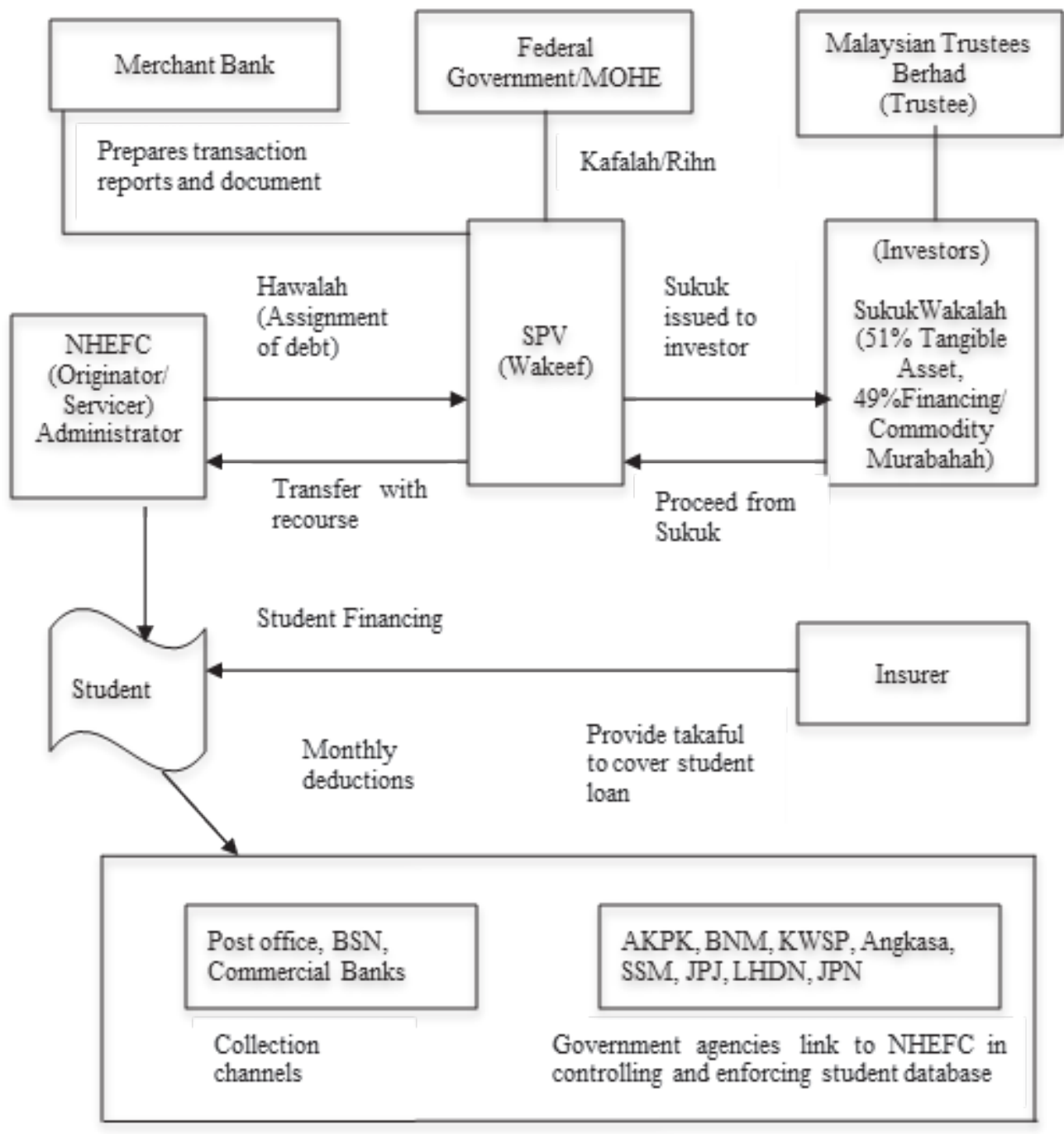

Figure 1: Framework of Student Financing Securitisation

wages increase. The employer will provide full cooperation and information with the NHEFC in providing information to the EPF in making the monthly payments proceed smoothly.

\subsubsection{Angkasa - National Cooperative Society in Malaysia}

The Cooperative Agency is a mediator for borrowers who work as government employees. The monthly payment deduction will be made through the monthly payslip, whereby Angkasa will process payments to the NHEFC on the behalf of the borrower. Government employees should cooperate with the cooperatives and make monthly deductions for loan repayment to avoid future inconveniences, such as disciplinary issues, promotion detention, and more.

\subsubsection{SSM - Registrar of Malaysian Companies}

The Companies Commission of Malaysia will work with NHEFC to facilitate lenders who make monthly payments. The commission has its branches located in each state to ease borrowers in making payments. If an entrepreneur who has a loan with NHEFC fails to make the payment within the stipulated time period, then the Commission may withhold the renewal of their annual license.

\subsubsection{JPJ - National Road Transport Department}

Authorities such as the Road Transport Department have a wide network system, whereby borrowers who require the renewal of their vehicle license must deal with 
the department annually, thus ensuring that arrears are paid accordingly.

\subsubsection{LHDN - Inland Revenue Board}

The Inland Revenue Board plays a central role in collecting government revenue for each taxable taxpayer. Borrowers may be required to have a tax nook so as to facilitate their payment-making processes after graduation and working. Such tax structures have been implemented in developed countries such as the UK, USA, Australia, and others, which allow the tax collection to be done efficiently. The government through the (Ministry of Finance, 2019) has introduced new tax system during the annual budget for year 2020 for any individuals who are 18 years old and older. They will be allocated a tax number so that their tax structure will follow the tax system implemented in developed countries, whereby the tax system will link to a student loan and thus improve student loan repayment processes.

\subsubsection{JPN - National Registration Office}

The National Registration Department is in charge of safeholding the personal data of borrowers and beneficiaries alike, which can assist the NHEFC in facilitating loan payment collection.

\section{Conclusion and Recommendations}

As Malaysia is known as the world's highest sukuk issuer, the introduction of a new Islamic Student Financing Securitisation will attract Muslim investors from foreign states, especially from the Middle East countries. Statistics has shown that the country ranks first in issuing sukuk globally, whereby the current industry is worth USD2 trillion and grows by $17 \%$ per annum, as well as producing the first green sukuk worldwide. The government through its Annual Budget 2020 aims to strengthen the Islamic finance sector and give incentives to corporations that can issue Sukuk Wakalah. Likewise, many investors from the Middle East countries have withdrawn their investments from the West due to the uncertainties of economy world trade as a result of the USAChina crisis. In fact, the uncertainty due to Brexit crisis in the UK has also affected their investment landscape, which is overpriced, and evidenced by the withdrawals of foreign direct investment origin from Europe. As such, investors are more attracted to invest in Islamic finance products, which are resilient during crisis, especially in subprime mortgage as an alternative financing for raising funds, namely by issuing Islamic student financing securitisation (Bakri et al., 2018).

Therefore, the testimony due to the successful launch of Malaysia as the first green sukuk 2017 worldwide serves as the motivation for proposing sukuk as a creative and cheaper debt financing alternative in the near future by promoting Islamic finance worldwide (Shabbir et al., 2019). Since Islamic securitization is a component of Islamic securities in Malaysia, the investigation was emphatically spurred to propose the system of Islamic Securitization Student Financing for the markets. Islamic sukuk considers a wide range of scope as an elective type of worldwide financing and venture (Sairally, 2015), especially for resourcesponsored protections (Wilson, 2014). Meanwhile, the wakalah structure is especially valuable when the hidden resources is accessible to the originator and can be utilized to aid in sukuk issuance, as it involves a pool or arrangement of advantages or ventures rather than specific substantial resource or resources rather than mudharabah or musharakah (represent proprietorship). Additionally, Islamic securitization as a component of Islamic bonds in Malaysia propelled the investigation to firmly propose the system for Islamic Securitization Student Financing, which will fulfil the commitment to the general population concurring Maqasid Shariah Dharuriyah or Hajiyat.

\section{References}

Ali, R., Ismail, S., \& Bakri, M. (2015). Proposed Islamic educational loan-backed securities for quality life of university graduates in Malaysia. Procedia-Social and Behavioral Sciences, 201, 85-92. https://doi.org/10.1016/j.sbspro.2015.08.134

Ande, R. A., Gunasekaran, A., Murugesan, P., \& Natarajan, T. (2017). Brand resonance score for CBBE model: An application in financial services. Benchmarking: An International Journal, 24(6),1490-1507. https://doi.org/10.1108/BIJ-07-2015-0073

Ayotte, K., \& S. Gaon. (2005). Asset-backed securities: Costs and benefits of bankruptcy remoteness. Review of Financial Studies, 24(4),1299-1335. https://doi.org/10.2139/ssrn.687259

Bakri, M. H., Ali, R., \& Ismail, S. (2016). Developing Primary Market Spread and Measuring Financial Performance of Staff Housing Government Loans. In: Proceedings of the 1st AAGBS InternationalConferenceonBusinessManagement(pp.501-511). https://doi.org/10.1007/978-981-287-426-9_44

Bakri, M. H., Ali, R., \& Ismail, S. (2015). The Study of Residential Mortgage Backed Securities During Subprime Mortgage: Malaysian Experience. Advanced Science Letters, 21(5), 1468-1472. https://doi.org/10.1166/asl.2015.6073

Bakri, M. H., Sufian, F, Baharom, A. H., \& Ismail, S. (2018). Determinant of Securitization Spread in Malaysia. International Journal of Business and Society, 19(3), 904-917.

Barr, N. (2003) Financing Higher Education: Lessons from the UK Debate. Political Quarterly, 74(3), 371-381. https://doi. org/10.1111/1467-923X.00546

Black, F., \& Scholes, M. (1973). The Pricing of Options and Corporate Liabilities. Journal of Political Economy, 81(3), 637-654. http://dx.doi.org/10.1086/260062 
Cartwright, S., \& Pappas, C. (2008). Emotional intelligence, its measurement and implications for the workplace. International Journal of Management Reviews, 10(2), 149-171. doi: 10.1111/j.1468-2370.2007.00220.x

Chapman, B. (2006). Government Managing Risk: Income contingent loans for social and economic progress. London, UK: Routledge. https://doi.org/10.4324/9780203488522

Chapman, B., \& A. Harding. (1993). Australian student loans. The Australian Economic Review, 26(1), 61-75. https://doi. org/10.1111/j.1467-8462.1993.tb00772.x

Chapman, B., \& Ryan, C. (2005). The access implications of income-contingent charges for higher education: lessons from Australia. Economics of Education Review, 24(5), 491-512. https://doi.org/10.1016/j.econedurev.2004.08.009

Chapra, M. (2008). Socio-Economic Justice and the Muslim World. Policy Perspectives, 5(1), 47-67.

Fan, G.-Z., Sing, T. F., Ong, S. E., \& Sirmans, C. F. (2004), Governance and Optimal Finance For Asset-Backed Securitization. Journal of Property Investment \& Finance, 2(5), 414-434. doi: 10.1108/14635780410556898

Friedman, M. (1955). The role of government in education. New Brunswick, NJ: Rutgers University Press.

Giddy, I. H. (2004). Asset Securitization in Asia. New York, New York University.

Hanim Kamil, K., Abdullah, M., Shahimi, S., \& Ghafar Ismail, A. (2010). The subprime mortgages crisis and Islamic securitization. International Journal of Islamic and Middle Eastern Finance and Management, 3(4), 386-401. https://doi. org/10.1108/17538391011093315

Hashim, N. A. (2018). Malaysian Sukuk: A Superior Alternative to Traditional Bonds. The Malaysian Reserve. Retrieved December 11, 2018, from: https://themalaysianreserve. com/2018/12/11/malaysian-sukuk-a-superior-alternative-totraditional-bonds/

Hartung, D. D., Laterza, R. D., \& McGarvey, S. (2006). Methodology FFELP Student Loan ABS Criteria. New York, NY: DBRS, Inc.

Hsing, Y., \& Chang, H. S. (1996). Testing Increasing Sensitivity of Enrolment at Private Institutions to Tuition and Other Costs. American Economist, 40(1), 40-45. https://doi.org/10.1177\% 2F056943459604000106

Hoda, N, Jafri, S. A., Ahmad, N., \& Hussain, S. M. (2020). An Empirical Testing of a House Pricing Model in the Indian Market. Journal of Asian Finance, Economics and Business, 7(8), 33-40. https://doi.org/10.13106/jafeb.2020.vo17.no8.033

Idris, N. H., Yazid, Z. A., Faique, F. A., Daud, S., Ismail, S., Bakri, M. H., \& Taib, N. M. (2016). Financial literacy and debt burden among Malay youth workers in Malaysia. Advanced Science Letters, 22(12), 4288-4292. https://doi.org/10.1166/ asl.2016.8130

Ismail, S., Bakri, M. H., Ali, R., \& Noor, A. M. (2014). Developing a Framework of Islamic Student Loan-backed Securitization.
Procedia-Social and Behavioral Sciences, 129, 380-387. https://doi.org/10.1016/j.sbspro.2014.03.691

Jacobs, B. I. (2009). Tumbling tower of babel: subprime securitization and the credit crisis. Financial Analysts Journal, 65(2), 17-30. https://doi.org/10.2469/faj.v65.n2.6

Johnstone, D. B. (1986). Sharing the Costs of Higher Education: Student Financial Assistance in the United Kingdom, the Federal Republic of Germany, France, Sweden and the United States. New York, NY: The College Board.

Khan, A. (2008). Low Salaries can defer repayment NHEFC. Berita Harian Online, Retrieved July 27, 2008, from : https://www. bharian.com.my/berita/nasional/2020/08/717879/bayaranbalik-ptptn-ditangguh-hingga-31-disember

Lazzaro, J. (2008). Students loan rates could rise as credit crunch hits student loan backed bonds. Retrieved April 6, 2008, from: http://www.bloggingstocks.com

Lemmon, M., Liu, L. X., Mao, M. Q., \& Nini, G. (2014) Securitization and capital structure in nonfinancial firms: an empirical investigation. Journal of Finance, 69, 1787-1825. https://doi.org/10.1111/jofi.12128

Menon, M. E. (1998). Factors influencing the demand for higher education: The case of Cyprus. Higher Education, 35, 251-266. https://doi.org/10.1023/A:1003047014179

Merton, R. (1973). Theory of Rational Option Pricing. Journal of Economics and Management Science, 4(1), 141-183. https:// doi.org/10.1142/9789812701022_0008

Michael, C. (1999). Rising Tuition Fees: Measuring the Impact upon undergraduate Enrolment in Ontario 1977/78-1996/97. In: the Canadian Institutional Research and Planning Association, Quebec City, October 24-26, 1999.

Ministry of Finance. (2013). Annual Budget 2014. The Malaysian Treasury, Putrajaya.

Ministry of Finance. (2019). Annual Budget 2020. The Malaysian Treasury, Putrajaya.

Mueller, R. E., \& Rockerbie, D. W. (2004). Issues in Education Demand: The Ontario Experience. Discussion paper prepared for Higher Education in Canada, John Deutsch Institute for the Study of Economic Policy, Queen's University, February 13-14, 2004.

National Higher Education Fund. (2013). Info National Higher Education Fund. Kuala Lumpur, Malaysia.

National Higher Education Fund. (2019). Paperwork Public Consultation. Kuala Lumpur, Malaysia.

Phuoc, L. T. (2018). Jensen's Alpha Estimation Models in Capital Asset Pricing Model. Journal of Asian Finance, Economics and Business, 5(3), 19-29. http://doi.org/10.13106/jafeb.2018.vol5. no3.19

Phuoc, L. T., Kim, K. S., \& Su, Y. (2018). Reexamination of Estimating Beta Coefficient as a Risk Measure in CAPM. Journal of Asian Finance, Economics and Business, 5(1), 11-16. http://dx.doi.org/10.13106/jafeb.2018.vol5.no1.11 
Sairally, B. S., Muhammad, M., \& Mustafa, M. M. (2015). Structuring Innovative Tier 2 (T2) Capital Instruments under Basel Iii: A Sharī'ah Perspective. ISRA International Journal of Islamic Finance, 7(2), 163-190.

Sharif, S. M., Nizam, N. Z., Rashid, N. A., Masrom, N. R., \& Bakri, M. H. (2018). Role of Values and Competencies in University Intellectual Property Commercialization: A Critical Review. The Turkish Online Journal of Design, Art and Communication. 887-904. https://doi.org/10.7456/1080SSE/125

Sarpong, O., \& Eboateng, K. (2002). An Analytical Study Of The Labour Market For and Social Development Imperatives of South Africa in the 21 Century. Pretoria, CHE.

Shabbir, M., \& Rehman, A. (2019). Layers of misconceptions about Islamic banking. Journal of Islamic Marketing, 10(3), 874-892. https://doi.org/10.1108/JIMA-02-2018-0026
Willett, D. (2011). Higher education: Funding and affordability. OECD Observer. Retrieved from https://oecdobserver.org/ news/fullstory.php/aid/3714/Higher_education:_Funding and_affordability.html

Wilson, R. (2008). Innovation in the structuring of Islamic sukuk securities. Humanomics, 24(3), 170-81. https://doi. org/10.1108/08288660810899340

Wilson, J. A. J. (2014). Islamic economics 2.0 - creating a halal wealth and knowledge economy. Whitepaper, Zawya, Thomson Reuters.

Woodhall, M. (1987). Student Loans. In: G. Psacharpoulos (Ed.), Economics of Education: Research and Studies (pp. 445-453). New York, NY: Pergamon.

Ziderman, A. (2004). Financing Universities in Developing Countries. Stanford Series on Education and Public Policy. London, UK: Falmer Press. 